\title{
Coordination Structures of Metalloporphyrins with $N$-Containing Cations in Complexes with Fullerenes
}

Dmitri V. Konarev, ${ }^{\circledR}$ and Rimma N. Lyubovskaya

Institute of Problems of Chemical Physics of Russian Academy of Sciences, Chernogolovka, Moscow region, 142432, Russia

@Corresponding authorE-mail: konarev@icp.ac.ru

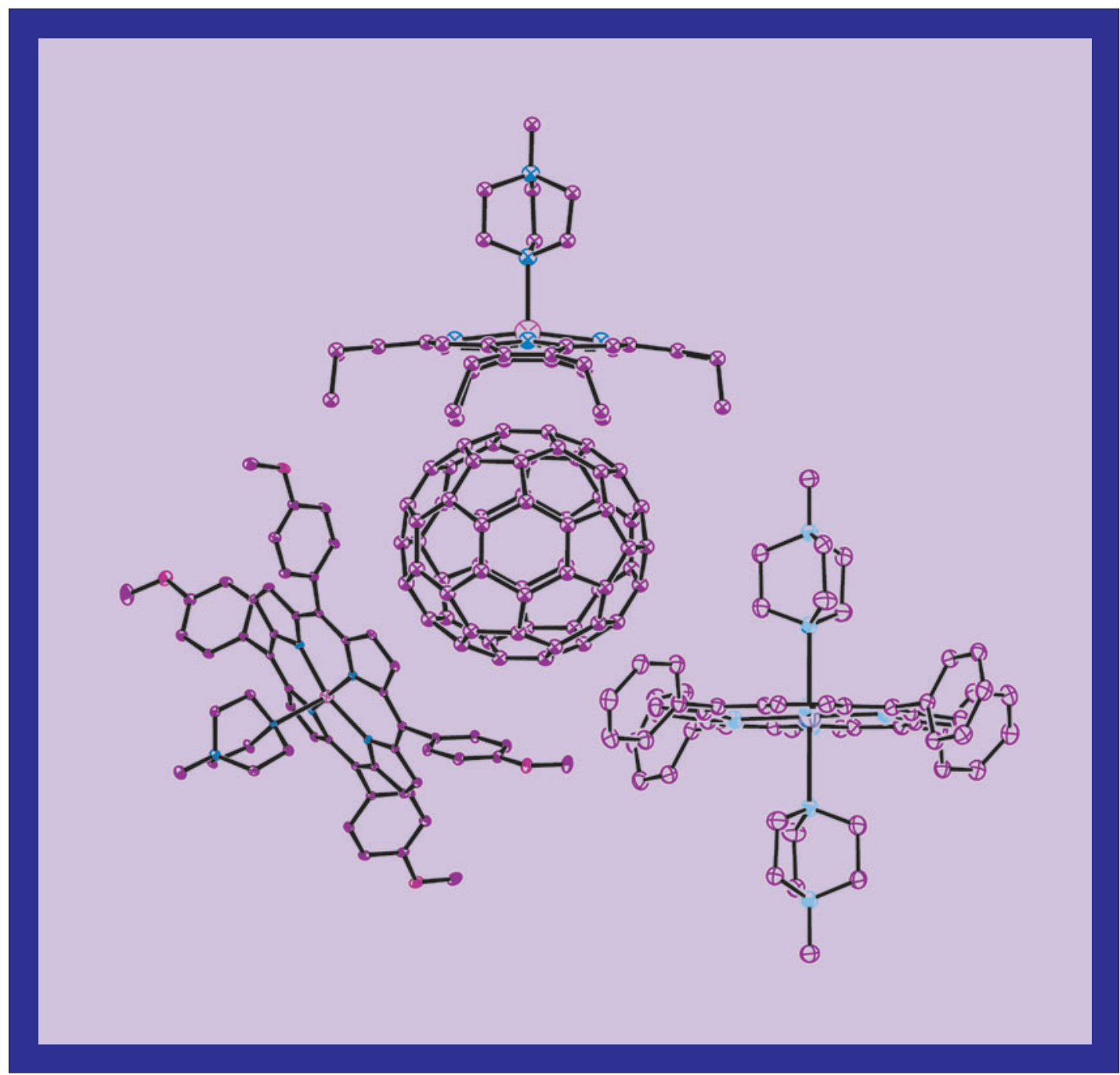


Ionic complexes of fullerenes with metalloporphyrins attract much attention due to promising photophysical and magnetic properties. We design these complexes using the coordination bonding between metalloporphyrins and $N$-containing cations $\left(M-N\left(L^{+}\right)\right.$bonds). In this review we discuss 1$) . C_{60}{ }^{-} C_{60}{ }^{2-}$ and $C_{70}{ }^{-}$complexes with $\left(\mathrm{MDABCO}^{+}\right)_{2} \cdot \mathrm{MI}^{\mathrm{II}} \mathrm{TPP}$ units $\left(\mathrm{MDABCO} \mathrm{O}^{+}\right.$is $\mathrm{N}$-methyldiazabicyclooctane cation, $M=\mathrm{Zn}$, Co, Mn, Fe, 1-6) having sixcoordinated metal centres; 2$). C_{60}{ }^{-}$complexes with $\left(M D A B C O^{+}\right) \cdot M^{I I} T M P P(M=Z n(7), C o(8))$ and $\left(M D A B C O^{+}\right) \cdot M^{I I} O E P$ units ( $M=\mathrm{Zn}, \mathrm{Co}, \mathrm{Mn}, \mathrm{Fe}$, 9-12) having five-coordinated metal centres. We discuss synthesis of the complexes, structures of metalloporphyrins coordinatively bound with $N$-containing cations formed in the complexes with fullerenes, and the magnetic properties of the complexes.

Keywords: Octaethyl- and tetraphenylporphyrins, complexes, fullerenes, coordination.

\section{Introduction}

Fullerenes form variety of molecular and ionic complexes with metalloporphyrins. ${ }^{[1-6]}$ These complexes attract much attention since porphyrin molecules are able to form complexes not only with fullerenes but with variety of endometallofullerenes and chemically modified fullerenes..$^{[1,7-9]}$ That allows to investigate the molecular and electronic structures of new fullerene families. Design of ionic complexes of fullerenes and metalloporphyrins is a promising approach to study fullerenes in a charged state including anions of endometallofullerenes and chemically modified fullerenes. The other interesting possibility of this approach is the preparation and study of new $\sigma$-bonded structures from negatively charged fullerenes. Since fullerene anions have strong tendency for dimerization, polymerization or coordination lead to the new types of fullerene dimers, polymers and coordinatively bound units. ${ }^{[10]}$

Since fullerenes are relatively weak acceptors (in compare with planar $\pi$-acceptors tetracyanoethylene or tetracyanoquinodimethane) ${ }^{[11]}$ most of fullerene complexes with metalloporphyrins have only neutral ground state. ${ }^{[1-5]}$ We developed new approach for the preparation of ionic fullerene-porphyrin complexes which uses the relatively weak coordination bonding between metalloporphyrins and $\mathrm{N}$-containing cations (the $\mathrm{M}-\mathrm{N}\left(\mathrm{L}^{+}\right)$bonds). ${ }^{[12-17]}$

For example, $N$-methyldiazabicyclooctane cation (MDABCO ${ }^{+}$, Scheme 1 ) has a free nitrogen atom capable to coordinate to different metalloporphyrins. Since $\mathrm{MDABCO}^{+}$ can be a counter cation for the fullerene anions, neutral

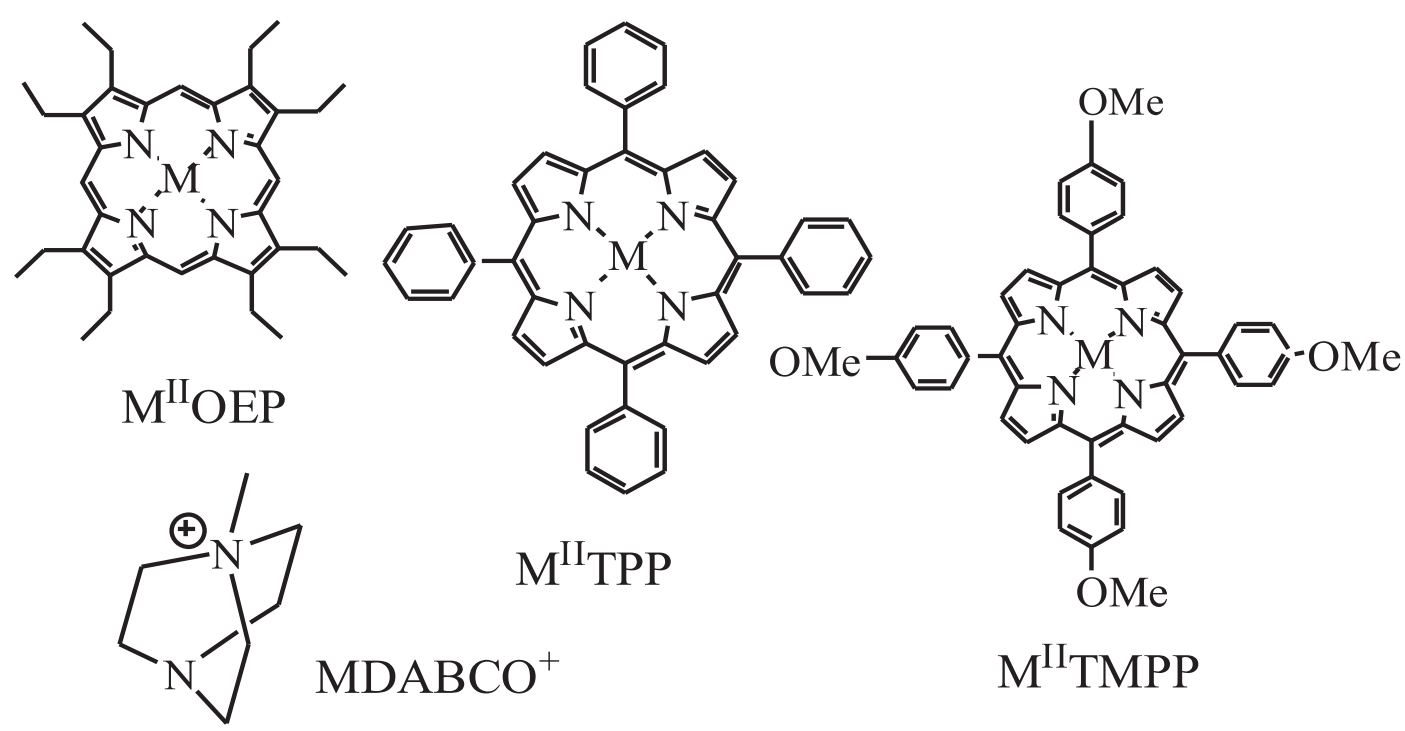

Scheme 1. 
metalloporphyrin molecules are involved into the ionic complexes with fullerenes in form of positively charged coordination assemblies: $\quad\left\{\left(\mathrm{MDABCO}^{+}\right)_{\mathrm{n}} \cdot \mathrm{M}^{\mathrm{II}}\right.$ porphyrin $\}$. $\cdot\left(\mathrm{C}_{60}{ }^{-}\right)_{\mathrm{n}}(\mathrm{n}=1$ and 2$)$. This approach allows to obtain ionic supramolecular complexes with fullerenes containing diamagnetic singly bonded $\left(\mathrm{C}_{70}{ }^{-}\right)_{2}$ dimers in $\left\{\left(\mathrm{MDABCO}^{+}\right)_{2}\right.$. $\left.\cdot \mathrm{Mn}^{\mathrm{IITPP}}\right\} \cdot\left\{\left(\mathrm{MDABCO}^{+}\right)_{2} \cdot\left\{\left(\mathrm{C}_{70}{ }^{-}\right)_{2}\right\}_{2} \cdot(\text { Solvent })_{\mathrm{x}} \quad(\mathrm{TPP}\right.$ is tetraphenylporphyrin, Scheme 1$)^{[12]}$ as well as unusual $\left(\mathrm{C}_{60}{ }^{-}\right)_{2}$ dimers bonded by two single bonds having biradical state at room temperature in $\left\{\left(\mathrm{MDABCO}^{+}\right) \cdot \mathrm{M}^{\mathrm{II}} \mathrm{TMPP}\right\}_{2} \cdot\left(\mathrm{C}_{60}{ }^{-}\right)_{2}$. .(Solvent) $\left(\mathrm{M}=\mathrm{Co}^{\mathrm{II}}\right.$, Zn; TMPP is tetrakis(4-methoxyphenyl) porphyrin, Scheme 1). ${ }^{[13,14]}$ Fullerene anions can also preserve the monomeric state in the complexes forming antiferromagnetically coupled $\mathrm{C}_{60}{ }^{\circ-}$ chains in $\left\{\left(\mathrm{MDABCO}^{+}\right)_{2}\right.$. $\left.\cdot \mathrm{M}^{\mathrm{II}} \mathrm{TPP}\right\} \cdot\left(\mathrm{C}_{60}{ }^{-}\right)_{2} \cdot(\text { Solvent })_{\mathrm{x}}{ }^{[12]}$ and $\left\{\left(\mathrm{MDABCO}^{+}\right) \cdot \mathrm{M}^{\mathrm{II}} \mathrm{OEP}\right\}$. $\cdot\left(\mathrm{C}_{60}{ }^{-}\right)_{2} \cdot(\text { Solvent })_{\mathrm{x}}$ complexes $(\mathrm{M}=\mathrm{Zn}, \mathrm{Co}, \mathrm{Mn} \text {, and Fe })^{[15,16]}$ (OEP is octaethylporphyrin, Scheme 1). Recently it was shown that not only fullerene radical anions but fullerene dianions can be involved into the ionic complexes with the coordination assemblies of metalloporphyrins allowing to study the electronic state of more negatively charged fullerenes. ${ }^{[17]}$ The supposed method of synthesis provides interesting possibility to study the coordination assemblies of metalloporphyrins with the coordination cations as well. This field of coordination chemistry of metalloporphyrins is not well studied

In this review we discuss synthesis, structures and magnetic properties of the ionic complexes of fullerenes and metalloporphyrins coordinated by $N$-containing cations.

\section{Results and Discussion}

$\mathrm{C}_{60}{ }^{\cdot-} \mathrm{C}_{60}{ }^{2-}$ and $\mathrm{C}_{70}{ }^{-}$complexeswith $\left(\mathrm{MDABCO} \mathrm{C}_{2}^{+}\right)^{\cdot} \mathrm{M}^{\mathrm{II}} \mathrm{TPP}$ units (1-6)

To prepare 1-5 we used the reduction of fullerenes with $\mathrm{CH}_{3} \mathrm{CH}_{2} \mathrm{SNa}$ in the presence of MDABCO-I excess in $\mathrm{C}_{6} \mathrm{H}_{4} \mathrm{Cl}_{2} /$ $\mathrm{C}_{6} \mathrm{H}_{5} \mathrm{CN}(19: 1)$ mixture. Then $\left(\mathrm{MDABCO}^{+}\right)$(fullerene- ${ }^{--}$) salt was precipitated from the solution by hexane in the presence of corresponding metalloporphyrin. The coordination of $\mathrm{MDABCO}^{+}$to metalloporphyrin is a key point for the formation of 1-5 since copper(II) tetraphenylporphyrin which can not coordinate $\mathrm{MDABCO}^{+}$does not form such complexes. For preparation of $\mathbf{6}$ an excess of $\mathrm{CH}_{3} \mathrm{CH}_{2} \mathrm{SNa}$, MDABCO-I and $\mathrm{C}_{60}$ were stirred in acetonitrile $\left(\mathrm{CH}_{3} \mathrm{CN}\right)$. The reduction occurred up to -2 charged state (according to the NIR spectra) and was accompanied by the cationic metathesis reaction. The addition of $o$-dichlorobenzene $\left(\mathrm{C}_{6} \mathrm{H}_{4} \mathrm{Cl}_{2}\right)$ and $\mathrm{Mn}^{\mathrm{II}} \mathrm{TPP}$ with further diffusion of hexane into the obtained solution yielded the crystals of $\mathbf{6}$. The compositions of 1-6 are listed in Table 1 . The compositions of $\mathbf{1}$ and $\mathbf{4}$ were determined from elemental analyses and those of 2, 3, 5 and $\mathbf{6}$ from X-ray structural analysis. The compositions of 1-4 are similar and differ only in the content of solvent molecules: $\left\{(\mathrm{MDABCO})_{2}\right.$. $\left.\cdot \mathrm{M}^{\mathrm{II} T P P}\right\} \cdot\left(\mathrm{C}_{60(70)}\right)_{2} \cdot\left(\mathrm{C}_{6} \mathrm{H}_{4} \mathrm{Cl}_{2}\right)_{2.2+x} \cdot\left(\mathrm{C}_{6} \mathrm{H}_{5} \mathrm{CN}\right)_{y} \quad(x=0-2.2$, $y=0$ - 1.8). Therefore, all these complexes most probably contain the same $\left(\mathrm{MDABCO}^{+}\right)_{2} \cdot \mathrm{M}^{\mathrm{II}} \mathrm{TPP}$ units and fullerene anions at 1:2 molar ratio. 5 has a composition of another character and involves free non-coordinated $\mathrm{MDABCO}^{+}$ cations additionally to $\left(\mathrm{MDABCO}^{+}\right)_{2} \cdot \mathrm{Mn}^{\mathrm{II}} \mathrm{TPP}$ units.

Metalloporphyrins coordinate two $\mathrm{MDABCO}^{+}$cations in both 2 and 3. Therefore, metal atoms are six-coordinated and have the octahedral environment at $\mathrm{M}^{\mathrm{II}}$ centres $(\mathrm{M}=$ Co (Figure 1a) and Mn). Previously such environment was reported for $\mathrm{Co}^{\mathrm{II}} \mathrm{TPP}$ in (piperidine) ${ }_{2} \mathrm{Co}^{\mathrm{II}} \mathrm{TPP}^{[18]}$ and by our knowledge was for the first time found for Mn ${ }^{\mathrm{II} T P P}$ since even in a large excess of $\mathrm{N}$-containing ligands such as pyridine and imidazole (L), $\mathrm{Mn}^{\mathrm{II}} \mathrm{TPP}$ forms only five-coordinated $\mathrm{L} \cdot \mathrm{Mn}^{\mathrm{II}} \mathrm{TPP}$ species. ${ }^{[19]}$ Most probably, crystal packing forces in the complex with fullerene facilitate the stabilization of six-coordinated metalloporphyrins. The Co $\cdots$ and $\mathrm{Mn}^{\cdots}$ $\mathrm{N}\left(\mathrm{MDABCO}^{+}\right)$distances of 2.475(2) and 2.553(2) $\AA$ indicate weak coordination of $\mathrm{MDABCO}^{+}$to metalloporphyrins. The elongation of Co- $\mathrm{N}$ axial coordination bonds from $2.157(3)$ to $2.436(2) \AA$ was observed when moving from five-coordinated (imidazole) $\cdot \mathrm{Co}^{\mathrm{II} T P P}$ to six-coordinated (piperidine) $)_{2} \cdot \mathrm{Co}^{\mathrm{II}} \mathrm{TPP}$. This elongation is a consequence of that an unpaired electron involved in the bonding is located on

Table 1. Composition of the complexes.

\begin{tabular}{|c|c|c|}
\hline $\mathrm{N}$ & Complex & Ref. \\
\hline 1 & $\left\{(\mathrm{MDABCO})_{2} \cdot \mathrm{ZnTPP}\right\} \cdot\left(\mathrm{C}_{60}\right)_{2} \cdot\left(\mathrm{C}_{6} \mathrm{H}_{4} \mathrm{Cl}_{2}\right)_{2.5} \cdot\left(\mathrm{C}_{6} \mathrm{H}_{5} \mathrm{CN}\right)_{0.5}$ & [12] \\
\hline 2 & $\left\{(\mathrm{MDABCO})_{2} \cdot \mathrm{Co}^{\mathrm{II}} \mathrm{TPP}\right\} \cdot\left(\mathrm{C}_{60}\right)_{2} \cdot\left(\mathrm{C}_{6} \mathrm{H}_{4} \mathrm{Cl}_{2}\right)_{4.4} \cdot\left(\mathrm{C}_{6} \mathrm{H}_{5} \mathrm{CN}\right)_{1.6}$ & [12] \\
\hline 3 & $\left\{(\mathrm{MDABCO})_{2} \cdot \mathrm{Mn}{ }^{\mathrm{II}} \mathrm{TPP}\right\} \cdot\left(\mathrm{C}_{60}\right)_{2} \cdot\left(\mathrm{C}_{6} \mathrm{H}_{4} \mathrm{Cl}_{2}\right)_{4.2} \cdot\left(\mathrm{C}_{6} \mathrm{H}_{5} \mathrm{CN}\right)_{1.8}$ & [12] \\
\hline 4 & $\left\{(\mathrm{MDABCO})_{2} \cdot \mathrm{Fe}^{\mathrm{II} T P P}\right\} \cdot\left(\mathrm{C}_{60}\right)_{2} \cdot\left(\mathrm{C}_{6} \mathrm{H}_{4} \mathrm{Cl}_{2}\right)_{2.2} \cdot\left(\mathrm{C}_{6} \mathrm{H}_{5} \mathrm{CN}\right)_{0.8}$ & [12] \\
\hline 5 & $\left\{(\mathrm{MDABCO})_{2} \cdot \mathrm{Mn}^{\mathrm{II}} \mathrm{TPP}\right\} \cdot(\mathrm{MDABCO})_{2} \cdot\left\{\left(\mathrm{C}_{70}\right)_{2}\right\}_{2} \cdot\left(\mathrm{C}_{6} \mathrm{H}_{4} \mathrm{Cl}_{2}\right)_{6} \cdot\left(\mathrm{C}_{6} \mathrm{H}_{5} \mathrm{CN}\right)_{5}$ & [12] \\
\hline 6 & $\left.\left\{\left(\mathrm{MDABCO}^{+}\right)_{2} \cdot \mathrm{Mn}^{\mathrm{II}} \mathrm{TPP}\right\} \cdot\left(\mathrm{C}_{60}{ }^{2-}\right) \cdot \mathrm{C}_{6} \mathrm{H}_{4} \mathrm{Cl}_{2}\right)_{4} \cdot\left(\mathrm{CH}_{3} \mathrm{CN}\right)_{2}$ & {$[17]$} \\
\hline 7 & $\left\{\left(\mathrm{MDABCO}^{+}\right) \cdot \mathrm{Co}^{\mathrm{II}} \mathrm{TMPP}_{2} \cdot\left(\mathrm{C}_{60}{ }^{-}\right)_{2} \cdot\left(\mathrm{C}_{6} \mathrm{H}_{4} \mathrm{Cl}_{2}\right)_{2.5} \cdot\left(\mathrm{C}_{6} \mathrm{H}_{5} \mathrm{CN}\right)_{1.5}\right.$ & [13] \\
\hline 8 & $\left\{\left(\mathrm{MDABCO}^{+}\right) \cdot \mathrm{ZnTMPP}\right\}_{2} \cdot\left(\mathrm{C}_{60}{ }^{-}\right)_{2} \cdot\left(\mathrm{C}_{6} \mathrm{H}_{4} \mathrm{Cl}_{2}\right)_{2.15} \cdot\left(\mathrm{C}_{6} \mathrm{H}_{5} \mathrm{CN}\right)_{1.85}$ & [14] \\
\hline 9 & $\left\{\left(\mathrm{MDABCO}^{+}\right) \cdot \mathrm{ZnOEP}\right\} \cdot\left(\mathrm{C}_{60}{ }^{--}\right) \cdot\left(\mathrm{C}_{6} \mathrm{H}_{5} \mathrm{CN}\right)_{0.75} \cdot\left(\mathrm{C}_{6} \mathrm{H}_{4} \mathrm{Cl}_{2}\right)_{0.25}$ & [16] \\
\hline 10 & $\left\{\left(\mathrm{MDABCO}^{+}\right) \cdot \mathrm{Co}^{\mathrm{II}} \mathrm{OEP}\right\} \cdot\left(\mathrm{C}_{60}{ }^{\bullet-}\right) \cdot\left(\mathrm{C}_{6} \mathrm{H}_{5} \mathrm{CN}\right)_{0.67} \cdot\left(\mathrm{C}_{6} \mathrm{H}_{4} \mathrm{Cl}_{2}\right)_{0.33}$ & [15,16] \\
\hline 11 & $\left\{\left(\mathrm{MDABCO}^{+}\right) \cdot \mathrm{Fe}^{\mathrm{II}} \mathrm{OEP}\right\} \cdot\left(\mathrm{C}_{60}{ }^{--}\right) \cdot\left(\mathrm{C}_{6} \mathrm{H}_{5} \mathrm{CN}\right)_{0.4} \cdot\left(\mathrm{C}_{6} \mathrm{H}_{4} \mathrm{Cl}_{2}\right)_{0.6}$ & [16] \\
\hline 12 & $\left\{\left(\mathrm{MDABCO}^{+}\right) \cdot \mathrm{Mn}^{\mathrm{II}} \mathrm{OEP}\right\} \cdot\left(\mathrm{C}_{60} \cdot-\right) \cdot\left(\mathrm{C}_{6} \mathrm{H}_{5} \mathrm{CN}\right)_{0.88} \cdot\left(\mathrm{C}_{6} \mathrm{H}_{4} \mathrm{Cl}_{2}\right)_{0.12}$ & [16] \\
\hline
\end{tabular}



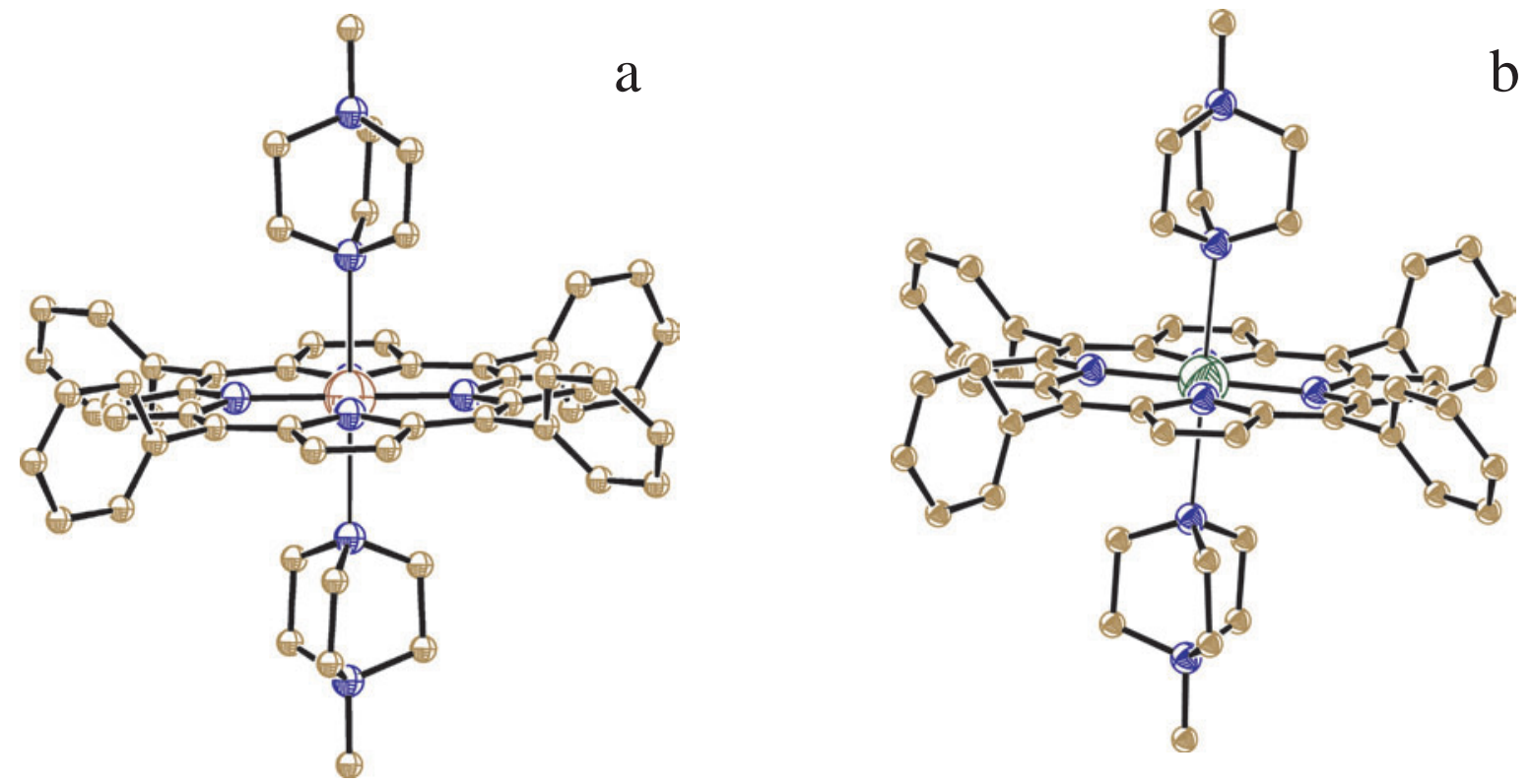

Figure 1. Coordination units formed with cobalt(II) and manganese(II) tetraphenylporphyrins: (a) (MDABCO $)_{2} \cdot \mathrm{Co}^{\mathrm{II} T P P}$ in 2 and (b) $\left(\mathrm{MDABCO}^{+}\right)_{2} \cdot \mathrm{Mn}^{\mathrm{II}} \mathrm{TPP}$ in $5 \cdot{ }^{[12]}$

$d_{z^{2}}$-orbital, which pointed directly to the two nitrogen atoms of axial ligands. ${ }^{[18,20]}$ The removal of the electron from $d_{\mathrm{z}^{2}}$-orbital in $\mathrm{Co}^{\mathrm{III}} \mathrm{TPP}^{+}$leads to the noticeable shortening of axial Co-N bonds in (piperidine) ${ }_{2} \cdot \mathrm{Co}^{\mathrm{III}} \mathrm{TPP}^{+}$to $2.060(3) \AA{ }^{[21]}$ For the same reason, the $\mathrm{Mn}-\mathrm{N}$ axial coordination bond elongates in the (MDABCO) $)_{2} \mathrm{Mn}^{\mathrm{II}} \mathrm{TPP}$ units. This implies that an unpaired electron of Mn ${ }^{\mathrm{II}} \mathrm{TPP}$ involved in the bonding with $\mathrm{MDABCO}^{+}$ should also localize on $d_{\mathrm{z}^{2}}$-orbital. Additional contribution to the elongation of $\mathrm{M}-\mathrm{N}$ bonds in $\left(\mathrm{MDABCO}^{+}\right)_{2} \cdot \mathrm{M}^{\mathrm{II}} \mathrm{TPP}(\mathrm{M}=$ $\mathrm{Co}$ and $\mathrm{Mn}$ ) can provide the repulsion between two positive charges of $\mathrm{MDABCO}^{+}$cations. Porphyrin macrocycles are nearly planar with root mean square deviations (rms) of 0.033 and $0.064 \AA$ for 2 and 3. The cobalt atom is in the porphyrin plane with the averaged length of the equatorial Co-N bonds of 1.988(2) $\AA$ ), what is close to that observed for six-coordinated (piperidine) $)_{2} \cdot \mathrm{Co}^{\mathrm{II}} \mathrm{TPP}(1.987(2) \AA) \cdot{ }^{[18]}$ The length of equatorial
Mn-N bonds is averaged in 3 at 2.096(2) $\AA$ and is close to that in high-spin ( $\mathrm{S}=5 / 2) \mathrm{Mn}^{\mathrm{II}} \mathrm{TPP} \cdot\left(\mathrm{C}_{6} \mathrm{H}_{5} \mathrm{CH}_{3}\right)_{2}\left(2.084(2) \AA^{[22]}\right)$.

The geometric parameters of $(\mathrm{MDABCO})_{2} \cdot \mathrm{Mn}^{\mathrm{II}} \mathrm{TPP}$ units in $\mathbf{5}$ (Figure 1b) and $\mathbf{6}$ are nearly the same as those in 3. Coordinated nitrogen atoms of two $\mathrm{MDABCO}^{+}$cations and metal atom lie along a straight line in 2, 3, 5 and $\mathbf{6}$, which is nearly perpendicular to the porphyrin plane in 2 and $3\left(88^{\circ}\right)$ and forms an angle of $85^{\circ}$ in 5 and $87.3^{\circ}$ in $\mathbf{6}$. In previously described (piperidine) ${ }_{2} \cdot \mathrm{Co}^{\mathrm{II}} \mathrm{TPP}$ this line forms an angle of about $89^{\circ}$ with the porphyrin plane. ${ }^{[18]}$ The Mn$\mathrm{N}\left(\mathrm{MDABCO}^{+}\right)$distances in $\mathbf{5}$ and $\mathbf{6}$ are long (Table 2) also indicating the essential destabilization of these coordination units. The averaged lengths of $\mathrm{Mn}-\mathrm{N}$ equatorial bonds in $\mathbf{5}$ and $\mathbf{6}$ (Table 2) are close to those in $\mathbf{3}$ and high-spin $\mathrm{Mn}{ }^{\mathrm{II}} \mathrm{TPP} \cdot\left(\mathrm{C}_{6} \mathrm{H}_{5} \mathrm{CH}_{3}\right)_{2} \cdot{ }^{[22]}$ The elongation of $\mathrm{Mn}-\mathrm{N}(\mathrm{TPP})$ bonds is associated with the singly occupied $d_{\left(\mathrm{x}^{2}-\mathrm{y}^{2}\right)}$-orbital in

Table 2. Geometric parameters of six-coordinated $\mathrm{Mn}^{\mathrm{II}} \mathrm{TPP}$ in high- and low-spin states. ${ }^{[17]}$

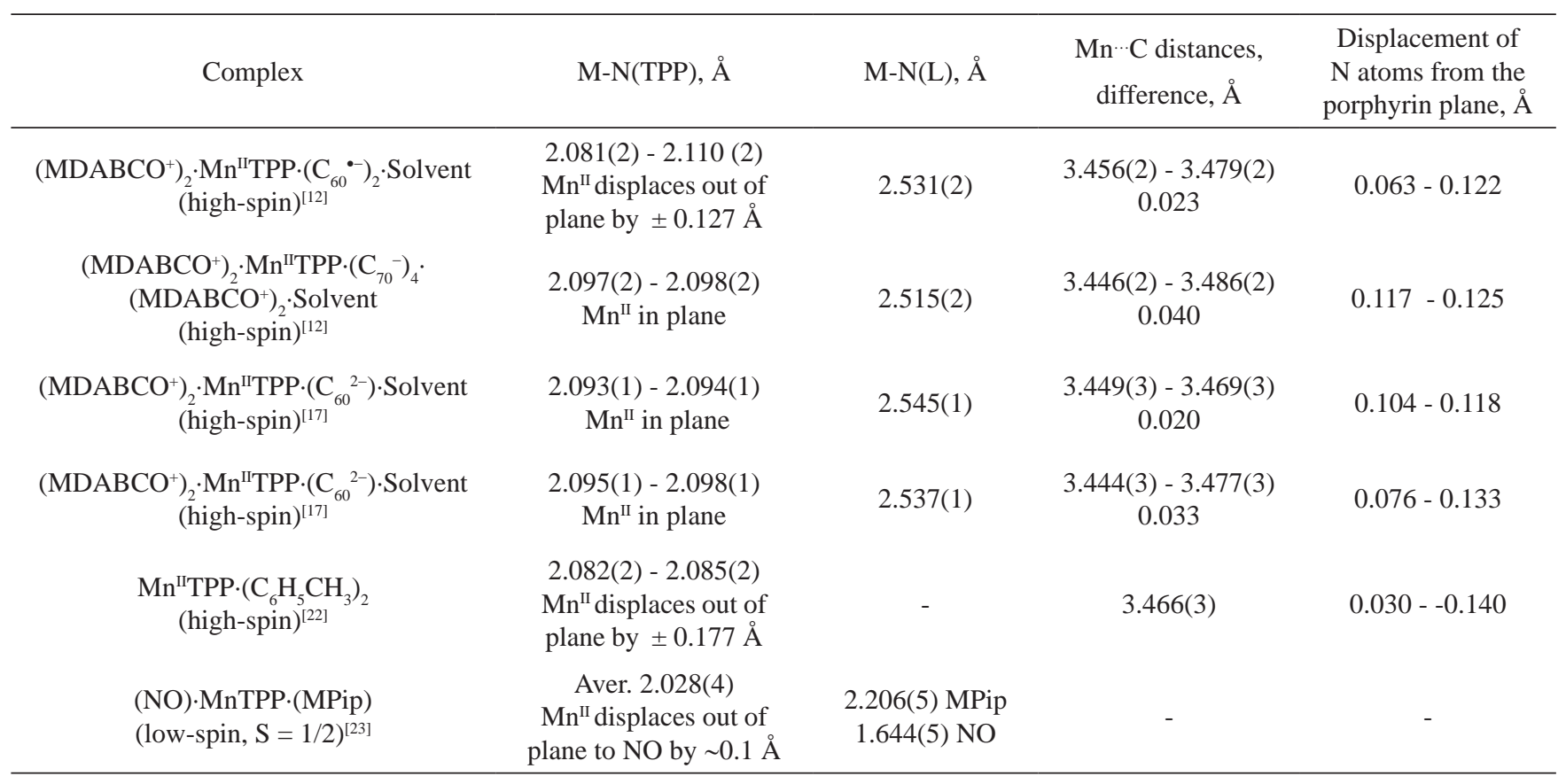




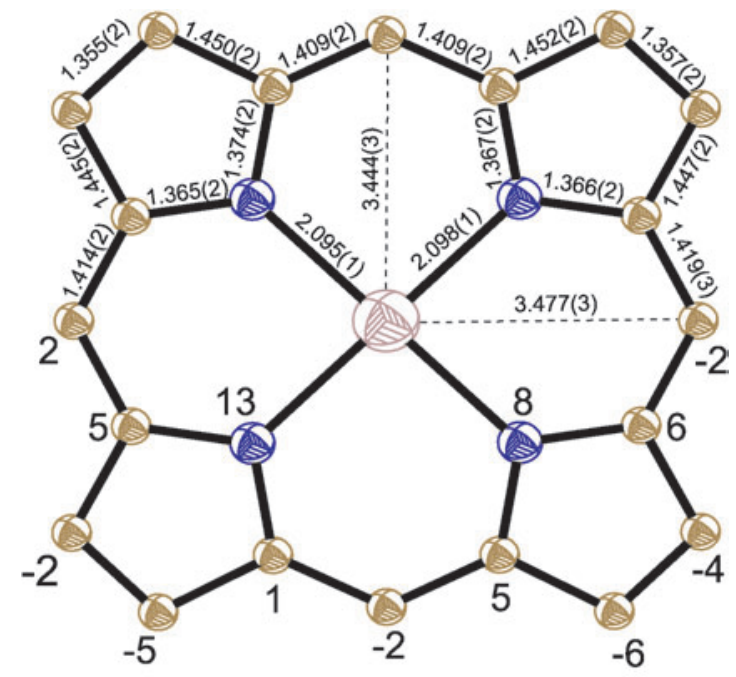

Figure 2. The structure of $\mathrm{Mn}^{\mathrm{II}} \mathrm{TPP}$ porphyrin core in 6. Upper half shows the structurally independent bond lengths and the lower half shows perpendicular displacements of the atoms (in the 0.01 $\AA$ units) from the mean 24-atom porphyrin plane. ${ }^{[17]}$

high-spin state of $\mathrm{Mn}^{\mathrm{II}} \mathrm{TPP}$, which is antibonding relative to the Mn-N(TPP) bonds.

Geometry of Mn ${ }^{\mathrm{II}} \mathrm{TPP}$ macrocycle is defined to a great extent by the spin state of $\mathrm{Mn}^{\mathrm{II}}$ atoms. We analyzed the geometric parameters of $\left(\mathrm{MDABCO}^{+}\right)_{2} \cdot \mathrm{Mn}^{\mathrm{II}} \mathrm{TPP}$ units in the complexes with fullerenes (Figure 2, Table 2). The degree of radial distortion of the porphyrin core can be estimated from the difference in the length of two $\mathrm{Mn} \cdots \mathrm{C}$ distances, and the perpendicular displacements of the atoms from the 24-atom porphyrin plane (Figure 2). The largest displacements were found for the nitrogen atoms of pyrrole rings (these values are listed in Table 2). The $\mathrm{Mn}^{\mathrm{II}}$ atoms are positioned exactly in the porphyrin plane in $\left(\mathrm{MDABCO}^{+}\right)_{2} \cdot \mathrm{Mn}^{\mathrm{II}} \mathrm{TPP}$ when it forms complex 5. ${ }^{[12]}$ That results in the largest radial expansion of the porphyrin core (Table 2). For $\left(\mathrm{MDABCO}^{+}\right)_{2} \cdot \mathrm{Mn}^{\mathrm{II}} \mathrm{TPP}$ units in 3, the thermal parameter of $\mathrm{Mn}^{\mathrm{II}}$ atom for the vibration perpendicular to the porphyrin plane is essentially higher than that of $\mathrm{N}$ atoms, and the disorder model in which $\mathrm{Mn}^{\mathrm{II}}$ atom was distributed between two symmetry equivalent outof-plane positions with isotropic temperature factors can be applied. However, the accuracy of the crystal structure determination does not allow one to refine simultaneously the position of $\mathrm{Mn}^{\mathrm{II}}$ atoms with anisotropic temperature factors because they show large correlations. ${ }^{[12]}$ The outof-plane displacement of $\mathrm{Mn}^{\mathrm{II}}$ atoms from the mean porphyrin plane estimated using this model was \pm 0.127 $\AA$. In this case moderate radial expansion of the porphyrin core is realized (Table 2). The $\mathrm{Mn}^{\mathrm{II}}$ atoms arranged exactly in the porphyrin plane in both crystallographically independent $\left(\mathrm{MDABCO}^{+}\right)_{2} \cdot \mathrm{Mn}^{\mathrm{II}} \mathrm{TPP}$ units in $\mathbf{6}$ since they are located in the centres of symmetry, whereas the radial expansion of the porphyrin core has moderate values (Table 2). Thus, all $\left(\mathrm{MDABCO}^{+}\right)_{2} \cdot \mathrm{Mn}^{\mathrm{II}} \mathrm{TPP}$ units manifest radial expansion of the porphyrin core. As this takes place $\mathrm{Mn}^{\mathrm{II}}$ atoms can locate in the porphyrin plane or displace out of this plane. The transition of $\mathrm{Mn}^{\mathrm{II}} \mathrm{TPP}$ to the low-spin state in (NO)-MnTPP.(MPip) decreases in the length of M-N(TPP) bonds (2.028(4) $\AA$ ), however, the data of the radial expansion of the porphyrin core is absent for this compound. ${ }^{[23]}$

Magnetic properties of $\mathbf{3}$ and $\mathbf{4}$ are defined by the contribution from $\mathrm{C}_{60}{ }^{-}$radical anions and the high-spin $\mathrm{Mn}^{\mathrm{II}} \mathrm{TPP}$ and $\mathrm{Fe}^{\mathrm{II}} \mathrm{TPP}$ porphyrins whereas those of $\mathbf{1}$ are defined by the contribution from $\mathrm{C}_{60}{ }^{-}$radical anions only. The Weiss temperatures were estimated to be $-13 \mathrm{~K}$ for $\mathbf{1}$ and $-2 \mathrm{~K}$ for $\mathbf{2}$ and $\mathbf{3}$. The $\left(\mathrm{C}_{70}{ }^{-}\right)_{2}$ dimers as well as the $\mathrm{C}_{60}{ }^{2-}$ dianions are diamagnetic and the magnetic behaviour of $\mathbf{5}$ and $\mathbf{6}$ is defined only by the contribution of high-spin Mn"ITPP
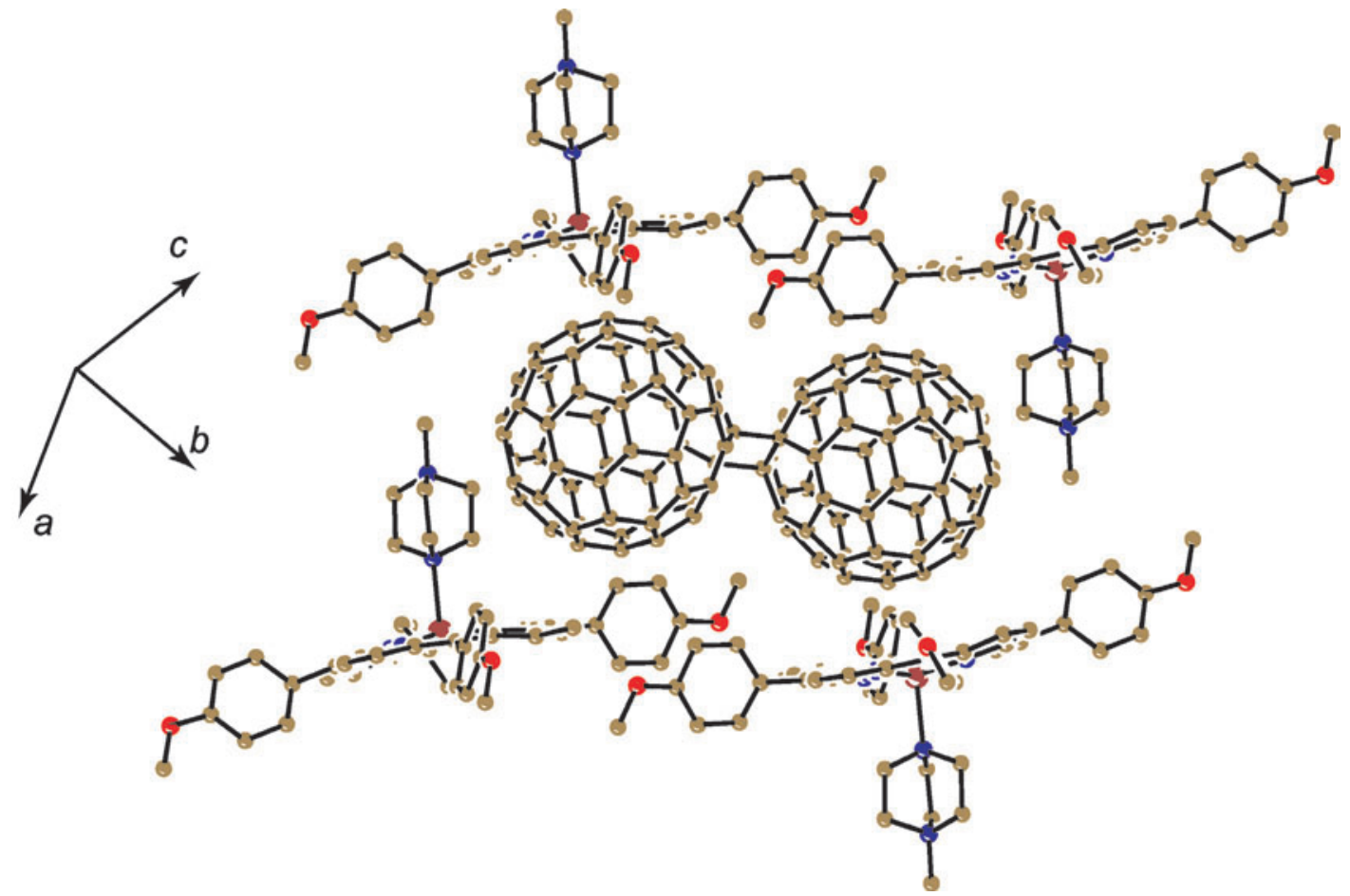

Figure 3. Fragment of the crystal structure of 7 showing the cage from the $\left(\mathrm{MDABCO}^{+}\right) \cdot \mathrm{Co}^{\mathrm{II}} \mathrm{TMPP}$ units accommodating the doubly bonded $\left(\mathrm{C}_{60}{ }^{-}\right)_{2}$ dimer. ${ }^{[13]}$ 
molecules which are isolated by the diamagnetic $\left(\mathrm{C}_{70}{ }^{-}\right)_{2}$ dimers or $\mathrm{C}_{60}{ }^{2-}$ anions. As a result the Weiss temperatures for these complexes are close to 0 .

The formation of $\left(\mathrm{C}_{60}{ }^{-}\right)_{2}$ dimers in the complexes with $\left(M D A B C O^{+}\right) \cdot M^{I I} T M P P$ units

An ionic complexes 7 and 8 contain negatively charged $\left(\mathrm{C}_{60}{ }^{-}\right)_{2}$ dimers, bonded by two $\mathrm{C}-\mathrm{C}$ bonds, and the coordination (MDABCO $\left.{ }^{+}\right) \cdot \mathrm{M}^{\mathrm{II}}$ TMPP units $(\mathrm{M}=\mathrm{Co}$ and $\mathrm{Zn})$. The composition of the complexes was determined by X-ray diffraction on a single crystal (Table 1).

The $\mathrm{MDABCO}^{+}$cation is a monodentate ligand and coordinates to $\mathrm{Co}^{\mathrm{II}} \mathrm{TMPP}$ in 7 by nitrogen atom with the Co $\cdots \mathrm{N}$ distance of $2.385 \AA$. Cobalt atom is five-coordinated and deviates by $0.084 \AA$ from the plane of four nitrogen atoms towards $\mathrm{MDABCO}^{+}$. Coordination between $\mathrm{Co}^{\mathrm{II}} \mathrm{TMPP}$ and $\left(\mathrm{C}_{60}{ }^{-}\right)_{2}$ dimers is absent, the shortest $\mathrm{Co} \cdots \mathrm{C}$ distances of 2.757 and $2.940 \AA$ are close to those distances in neutral $\mathrm{Co}^{\mathrm{II}} \mathrm{TMPP} \cdot\left(\mathrm{C}_{60}\right)_{2} \cdot\left(\mathrm{C}_{6} \mathrm{H}_{5} \mathrm{CH}_{3}\right)_{3}$ complex (2.65-2.67 A). ${ }^{[5]}$ A porphyrin cage accommodates $\left(\mathrm{C}_{60}{ }^{-}\right)$, dimers in 7 and completely isolates them one from another (Figure 3). Each cage consists of six $\left\{\left(\mathrm{MDABCO}^{+}\right) \cdot \mathrm{Co}^{\mathrm{II}} \mathrm{TMPP}\right\}$ units, two of which contact with dimer by free $\mathrm{Co}^{\mathrm{II}} \mathrm{TMPP}$ surface, four other units contact with dimer by $\mathrm{MDABCO}^{+}$cations with short $\mathrm{C}\left(\mathrm{MDABCO}^{+}\right)-\mathrm{C}\left(\left(\mathrm{C}_{60}{ }^{-}\right)_{2}\right)$ contacts in the 3.082$3.390 \AA$ range (only two of four such units are shown in Figure 3 for clarity).

Similar doubly bonded $\left(\mathrm{C}_{60}{ }^{-}\right)_{2}$ dimers are formed in $\mathbf{8}$. However, in this case the shortest $\mathrm{Zn} \cdots \mathrm{C}\left(\left(\mathrm{C}_{60}{ }^{-}\right)_{2}\right)$ distances are longer (3.02-3.17 $\AA$ ). That is due to the stronger coordination of $\mathrm{MDABCO}^{+}$to ZnTMPP (Figure $4 \mathrm{a}$ ) since N(MDABCO ${ }^{+}$).. $\mathrm{Zn}$ distance is noticeably shorter (2.280(4) $\AA$ ) and the displacement of $\mathrm{Zn}$ atom from the plane of four nitrogen atoms towards $\mathrm{MDABCO}^{+}$is larger $(0.265 \AA)$. Short Co $\cdots$ $\mathrm{C}\left(\left(\mathrm{C}_{60}{ }^{-}\right)_{2}\right)$ contacts provide complete order of $\left(\mathrm{C}_{60}{ }^{-}\right)_{2}$ dimers in 7 whereas weaker $\mathrm{Zn} \cdots \mathrm{C}\left(\left(\mathrm{C}_{60}{ }^{-}\right)_{2}\right)$ interaction results in the disorder of these dimers in $\mathbf{8}$ even at 120(2) K in spite of the Van-der-Waals interaction with the porphyrin plane is nearly the same in both complexes. These data allow to suppose that namely metal-fullerene interaction is responsible for the ordering of the fullerene dimers.

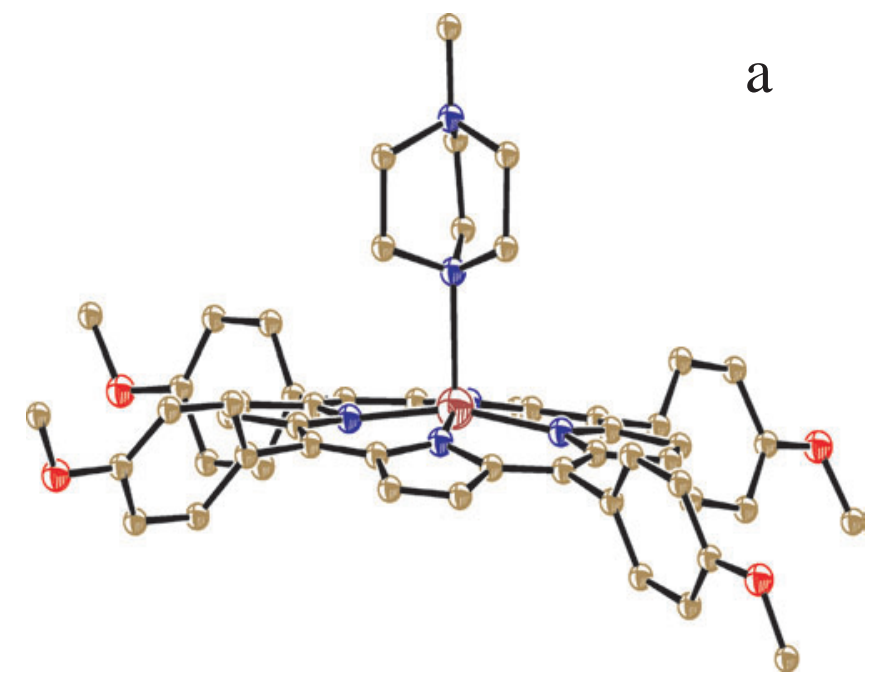

The magnetic properties of $\left(\mathrm{C}_{60}{ }^{-}\right)_{2}$ dimers, bonded by two $\mathrm{C}$-C bonds, are of a special interest since they have triplet state at $300 \mathrm{~K}$. Magnetic moment of 7 at this temperature is equal to $3.47 \mu_{\mathrm{B}}$ at $300 \mathrm{~K}$ and close to that calculated for a system of four noninteracting $1 / 2$ spins $\left(\mu_{\text {eff }}=3.46 \mu_{B}\right)$ per a formula unit. These spins are localized on $\mathrm{Co}^{\mathrm{II}} \mathrm{TMPP}$ and $\mathrm{C}_{60}{ }^{-}$(four units in total). Taking into account that the dimer is a single molecule, the presence of spins on both $\mathrm{C}_{60}{ }^{-}$units implies that this dimer should have a biradical state at 300 $\mathrm{K}$. The presence of paramagnetic $\mathrm{Co}^{\mathrm{IIT}} \mathrm{TMPP}$ and $\left(\mathrm{C}_{60}{ }^{-}\right)_{2}$ is justified by EPR since both species show individual signals. Intense EPR signal with $g=1.9997$ and the linewidth $(\Delta \mathrm{H})$ of $3.46 \mathrm{mT}$ at RT, which is close to those of the radical anions of $\mathrm{C}_{60}$ derivatives $\left(2.0000^{[24]}\right)$, was attributed to the $\left(\mathrm{C}_{60}{ }^{-}\right)_{2}$ dimers and broad signal with $g=2.2638$ and $\Delta H=30 \mathrm{mT}$

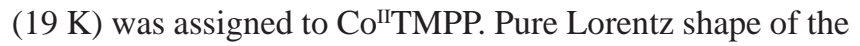
signal from the $\left(\mathrm{C}_{60}{ }^{-}\right)_{2}$ dimers is most probably the result of exchange interaction between $\mathrm{Co}^{\mathrm{II}} \mathrm{TMPP}$ and $\left(\mathrm{C}_{60}{ }^{-}\right)_{2}$, which averages $D$ and $E$ parameters and leads to the disappearance of triplet features of the signal. In contrast to 7 complex 8 contains diamagnetic and EPR silent $\left(\mathrm{MDABCO}^{+}\right) \cdot \mathrm{ZnTMPP}$ units. That allows us to observe the narrow Lorentz signal from the $\left(\mathrm{C}_{60}{ }^{-}\right)_{2}$ dimers $(g=2.0024$ and $\Delta H=0.277 \mathrm{mT})$ which narrows at temperature decrease $(0.17 \mathrm{mT}$ at $100 \mathrm{~K})$. The data of SQUID measurements for $\mathbf{8}$ can be fitted according to the Heisenberg model for the pairs of antiferromagnetically interacting spins with exchange interaction between them of $J / k_{\mathrm{B}}=-44.7 \mathrm{~K}$. Therefore, dimers have singlet $(S=0)$ ground state and exited $(S=1)$ triplet state.

\section{$\mathrm{C}_{60} \cdot{ }^{\cdot-}$ complexes with $(\mathrm{MDABCO}) \cdot \mathrm{M}^{\mathrm{II}} \mathrm{OEP}$ units}

The complexes 9-12 were obtained by the reduction of $\mathrm{C}_{60}$ by $\mathrm{CH}_{3} \mathrm{CH}_{2} \mathrm{SNa}$ in the presence of MDABCO-I with following precipitation of the obtained salt in the presence

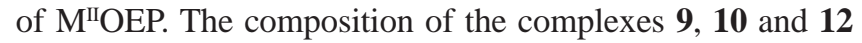
was determined by X-ray diffraction study on a single crystal whereas that of $\mathbf{1 1}$ by elemental analysis (Table 1). The $\mathrm{MDABCO}^{+}$cations coordinate to $\mathrm{M}^{\mathrm{II} O E P}$ as monodentate ligands forming positively charged coordination assemblies $\left(\mathrm{MDABCO}^{+}\right) \cdot \mathrm{M}^{\mathrm{II}} \mathrm{OEP}\left(\mathrm{M}=\mathrm{Zn}, \mathrm{Co}, \mathrm{Mn}\right.$, and Fe). The $\mathrm{M}^{\mathrm{II}}$ atoms are five-coordinated in these assemblies (Figure $4 \mathrm{~b}$ ).

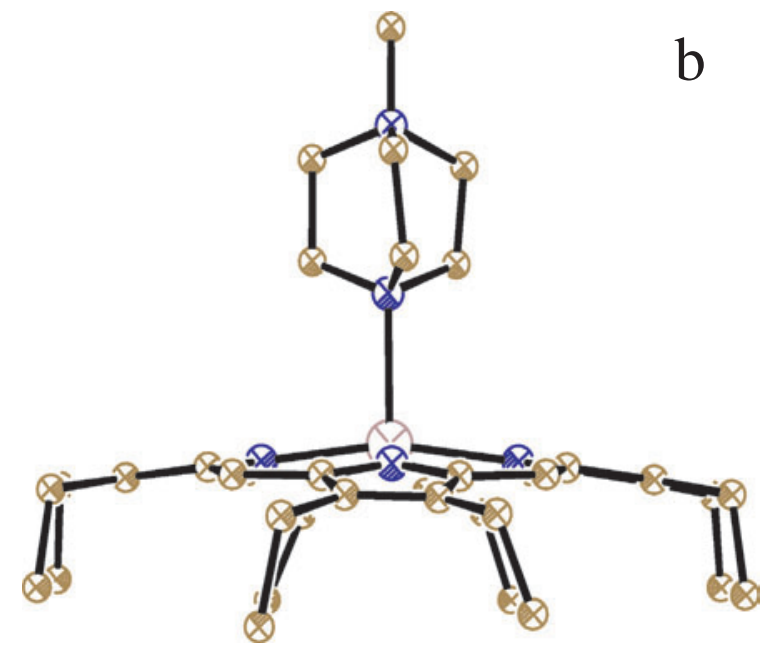

Figure 4. Coordination $\left(\mathrm{MDABCO}^{+}\right) \cdot \mathrm{ZnTMPP}$ units in 8 (a) and (MDABCO $\left.{ }^{+}\right) \cdot \mathrm{Mn}^{\mathrm{II}} \mathrm{OEP}$ units in 12 (b). 


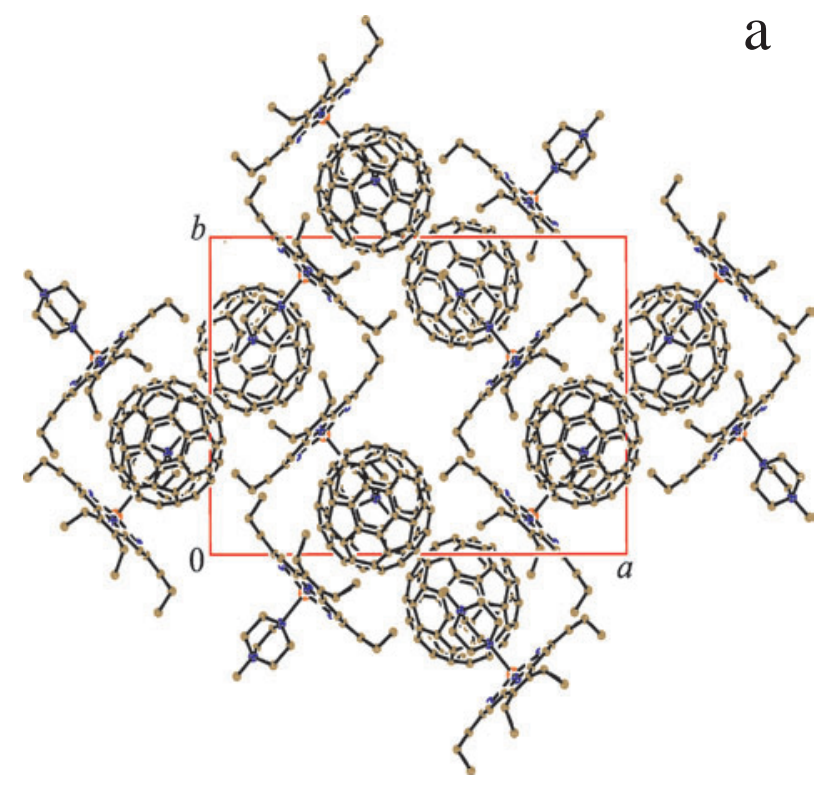

Figure 5. The view on the crystal structure of $\mathbf{9}$ along $c$-axis and zigzag fullerene chains (a); the view on the zigzag fullerene chains along $b$-axis (b). Solvent molecules are not depicted for clarity.

The length of $\mathrm{M}-\mathrm{N}\left(\mathrm{MDABCO}^{+}\right)$bonds changed in the following order: $\mathrm{Zn}(2.237(2))<\mathrm{Mn}^{\mathrm{II}}(2.301(1))<\mathrm{Co}^{\mathrm{II}}$ (2.340(3) $\AA$ ). $\mathrm{M}^{\mathrm{II}}$ atoms deviate from the plane of four nitrogen atoms towards $\mathrm{MDABCO}^{+}$cation by $0.042 \AA$ in 10, $0.239 \AA$ in 9 and $0.274 \AA$ in 12. The weaker $\mathrm{M}-\mathrm{N}$ bonds lead to smaller deviation of the metal atom from the plane of four nitrogen atoms. Since one coordination position is free in $\mathrm{M}^{\mathrm{II}}$ atom $\mathrm{C}_{60}{ }^{\cdot-}$ can be a second ligand for $\mathrm{M}^{\mathrm{II}} \mathrm{OEP}$.

The main structural motif of these complexes is zigzag chains of fullerenes, which occupy channels formed by four $\mathrm{M}^{\mathrm{II}} \mathrm{OEP}$ molecules (Figure $5 \mathrm{a}$ ). Due to the zigzag arrangement of fullerenes vacancies are formed in the chains, accommodating small $\mathrm{MDABCO}^{+}$cations (Figure 5b). The centre-to-centre distances between fullerenes in the chains are defined by the cation size. They are rather large (10.297 $\AA$ for 10, $10.560 \AA$ for 9 and $10.703 \AA$ for 12) and do not allow the formation of Van-der-Waals $\mathrm{C} \cdots \mathrm{C}$ contacts between $\mathrm{C}_{60}{ }^{-{ }^{-}}$in the chains.

$\mathrm{C}_{60}{ }^{--}$radical anions are arranged from the opposite site of the porphyrin macrocycle relative to the $\mathrm{N}$-containing cation. The shortest $\mathrm{M} \cdots \mathrm{C}\left(\mathrm{C}_{60}{ }^{--}\right)$distance among these complexes was found in $\mathbf{1 0}(2.508(4) \AA$ at $100 \mathrm{~K})$ and in this case the reversible formation of $\mathrm{Co}-\mathrm{C}$ coordination bond is observed. $\mathrm{M} \cdots \mathrm{C}\left(\mathrm{C}_{60}{ }^{--}\right)$distances in $\mathbf{9}$ and $\mathbf{1 2}$ are essentially longer (3.037 and $3.049 \AA$ at $100 \mathrm{~K}$, respectively) indicating the absence of coordination of $\mathrm{C}_{60}{ }^{--}$to $\left(\mathrm{MDABCO}^{+}\right) \cdot \mathrm{ZnOEP}$ or $\left(\mathrm{MDABCO}^{+}\right) \cdot \mathrm{Mn}^{\mathrm{II}} \mathrm{OEP}$ units. Nevertheless, $\mathrm{C}_{60}{ }^{\cdot-}$ radical anions form multiple short Van-der-Waals $\mathrm{N} \cdots \mathrm{C}$ and $\mathrm{C} \cdots \mathrm{C}$ contacts with the porphyrin macrocycles in these complexes since the macrocycles are concave-shaped and conform well to the spherical shape of $\mathrm{C}_{60}$.

The averaged length of $\mathrm{M}-\mathrm{N}(\mathrm{OEP})$ bonds in $\left(\mathrm{MDABCO}^{+}\right) \cdot \mathrm{Mn}^{\mathrm{II}} \mathrm{OEP}(\mathbf{1 2})$ is 2.107(2) $\AA$ and indicates the high-spin state of $\mathrm{Mn}^{\mathrm{II}} \mathrm{OEP}$. Close length of $\mathrm{Mn}-\mathrm{N}$ (porphyrin) bonds was found in high-spin $\mathrm{Mn}^{\mathrm{II}} \mathrm{TPP}$. $(1-\mathrm{MeIm})(2.128(7) \AA[26])$ and $\left(\mathrm{MDABCO}^{+}\right)_{2} \cdot \mathrm{Mn}^{\mathrm{II}} \mathrm{TPP}$ (2.081(1)-2.110(2) $\AA) .^{[12,17]}$

Magnetic properties of the complexes range from diamagnetic behaviour of $\mathbf{1 0}$ at low temperature (due to the formation of $\mathrm{Co}-\mathrm{C}\left(\mathrm{C}_{60}{ }^{-}\right)$bond) to strong antiferromagnetic interaction of spins in $\mathbf{9}, \mathbf{1 1}$ and $\mathbf{1 2}$ (the Weiss temperatures were estimated to be $-18,-42$ and $-2.5 \mathrm{~K}$, respectively). Complexes 9 and 12 contain chains of $\mathrm{C}_{60} \cdot{ }^{-}$radical anions, whereas 12 additionally contains high-spin $\left(\mathrm{MDABCO}^{+}\right) \cdot \mathrm{Mn}^{\mathrm{II}} \mathrm{OEP}$ units. Both complexes show AF interaction of spins, which is most probably realized in the fullerene chains. Additionally, each $\mathrm{C}_{60}{ }^{--}$has face-toface interaction with the porphyrin macrocycle. Therefore, magnetic interaction between $\mathrm{Mn}^{\mathrm{II}}$ centres and $\mathrm{C}_{60}{ }^{-{ }^{-}}$is also expected in 12. The EPR spectrum of $\mathbf{9}$ justifies the presence of exchange coupling between $\left(\mathrm{MDABCO}^{+}\right) \cdot \mathrm{Mn}^{\mathrm{II}} \mathrm{OEP}$ and $\mathrm{C}_{60} \cdot-$. Complex 11 manifests strongest antiferromagnetic interaction of spins. However, the absence of structural information does not allow the detailed interpretation of the magnetic data for this compound.

\section{Conclusions}

The tendency of metalloporphyrins, $\mathrm{M}^{\mathrm{II}}$ porphyrin, to extra-coordination can be successfully used in the design of supramolecular ionic $\mathrm{M}^{\mathrm{II}}$ porphyrin- $\mathrm{C}_{60}$ complexes: $\left\{\left(\mathrm{MDABCO}^{+}\right)_{\mathrm{n}} \cdot \mathrm{M}^{\mathrm{II}}\right.$ porphyrin $\} \cdot\left(\mathrm{C}_{60}{ }^{\cdot-}\right) \cdot(\text { Solvent })_{\mathrm{x}}(\mathrm{n}=1$ and 2). The driving force for the formation of these complexes is the coordination of $\mathrm{MDABCO}^{+}$to $\mathrm{M}^{\mathrm{II}}$ porphyrin $(\mathrm{M}=$ $\mathrm{Zn}, \mathrm{Co}, \mathrm{Mn}$ and $\mathrm{Fe}$ ). Porphyrins, which cannot coordinate this cation, for example $\mathrm{Cu}^{\mathrm{II}}$ porphyrins, do not form such complexes.

The synthesis of the series of complexes allows for the first time to study the coordination of $\mathrm{MDABCO}^{+}$and $\mathrm{C}_{60}{ }^{-}$ to $\mathrm{M}^{\mathrm{II} O E P}$ and compare their coordination ability. There is a competition between fullerenes and $N$-containing cations for the coordination to $\mathrm{M}^{\mathrm{II} O E P}$. From structural data we can conclude that fullerenes are weaker ligands than $\mathrm{MDABCO}^{+}$. As a result, the $\mathrm{M}^{\mathrm{II}}$ atoms display out of the porphyrin plane towards $\mathrm{N}$-containing ligand forming rather short $\mathrm{M}-\mathrm{N}\left(\mathrm{L}^{+}\right)$ bonds of 2.237(2)-2.340(3) $\AA$ length and that prevents the formation of stable coordination bonds between fullerenes and $\mathrm{M}^{\mathrm{II}}$ porphyrins. The smaller is the displacement of the 
metal(II) atom from the porphyrin plane towards $\mathrm{MDABCO}^{+}$ the shorter $\mathrm{M} \cdots \mathrm{C}\left(\mathrm{C}_{60}{ }^{-}\right)$contacts are formed. The smallest displacement of $\mathrm{Co}^{\mathrm{II}}$ atom and the shortest $\mathrm{Co} \cdots \mathrm{C}\left(\mathrm{C}_{60}{ }^{-}\right)$ distance were found namely in 10. It should be emphasized that the Co-C coordination bonds are really formed in $\mathbf{1 0}$ below $50 \mathrm{~K} \cdot{ }^{[15]}$ In 9 and 12 the larger $\mathrm{M} \cdots \mathrm{C}\left(\mathrm{C}_{60}{ }^{--}\right)$distances (> $3 \AA$ ) for $\mathrm{ZnOEP}$ and $\mathrm{Mn}^{\mathrm{II}} \mathrm{OEP}$ indicate the absence of coordination at $100 \mathrm{~K}$.

Coordination assemblies were found in a series of $\left\{\left(\mathrm{MDABCO}^{+}\right)_{2} \cdot \mathrm{M}^{\mathrm{II}} \mathrm{TPP}\right\} \cdot\left(\mathrm{C}_{60}{ }^{-}\right)_{2} \cdot(\text { Solvent })_{x}$ complexes with metal(II) tetraphenylporphyrins $(\mathrm{M}=\mathrm{Zn}, \mathrm{Co}, \mathrm{Mn}$ and $\mathrm{Fe}) .^{[12]}$ However, in this case two $\mathrm{MDABCO}^{+}$cations coordinate to each $\mathrm{M}^{\mathrm{II}}$ TPP with the formation of $\left(\mathrm{MDABCO}^{+}\right)_{2} \cdot \mathrm{M}^{\mathrm{II}} \mathrm{TPP}$ units and, as a result, the central metal(II) atoms of porphyrins are shielded from bonding with $\mathrm{C}_{60}{ }^{-}$. In the case of six-coordinated metalloporphyrins $\mathrm{M}-\mathrm{N}\left(\mathrm{L}^{+}\right)$bonds are rather long (2.475(2)-2.553(2) $\AA$ ) indicating essential destabilization of these coordination units. The $\mathrm{Mn}^{\mathrm{II}}$ and $\mathrm{Fe}^{\mathrm{II}}$ porphyrins are in high-spin state $(\mathrm{S}=5 / 2)$ and $(\mathrm{S}=2)$, respectively both for five- and six-coordinated porphyrins in the complexes with fullerenes. That was confirmed by the magnetic measurments.

The developed method of synthesis demonstrates high potential for the preparation of different $\sigma$-bonded structures of negatively charged fullerenes and coordinatively bound structures of metalloporphyrins with $N$-containing cations as well to obtain complexes with antiferromagnetic interaction of spins ranging from weak to strong.

Acknowledgements. The work was supported by RFBR grant N 06-03-32824.

\section{References}

1. Olmstead M.M., Costa K., Maitra D.A., Noll B.C., Phillips S.L., Van Calcar P.M., Balch A.L. J. Am. Chem. Soc. 1999, 121, 7090-7097.

2. Yudanova E.I., Konarev D.V., Gumanov L.L., Lyubovskaya R.N. Russ. Chem. Bull. 1999, 48, 718-721.

3. Boyd P.D.W., Hodgson M.C., Rickard C.E.F., Oliver A.G., Chaker L., Brothers P.J., Bolskar R.D., Tham F.S., Reed C.A. J. Am. Chem. Soc. 1999, 121, 10487-10495.

4. Konarev D.V., Neretin I.S., Slovokhotov Yu.L., Yudanova E.I., Drichko N.V., Shul'ga Yu.M., Tarasov B.P., Gumanov L.L.,
Batsanov A.S., Howard J.A.K., Lyubovskaya R.N. Chem. Eur. J. 2001, 7, 2605-2616.

5. Konarev D.V., Kovalevsky A.Yu., Li X., Neretin I.S., Litvinov A.L., Drichko N.V., Slovokhotov Yu.L., Coppens P., Lyubovskaya R.N. Inorg. Chem. 2002, 41, 3638-3646.

6. Pénicaud A., Hsu J., Reed C.A., Koch A., Khemani K.C., Allemand P.-M., Wudl F. J. Am. Chem. Soc. 1991, 113, 66986670.

7. Stevenson S., Rice G., Glass T., Harich K., Cromer F., Jordan M.R., Craft J., Hadju E., Bible R., Olmstead M.M., Maitra K., Fisher A.J., Balch A.L., Dorn H.C. Nature 1999, 401, 55-57.

8. Zheng M., Li F., Shi Z., Gao Y., Kadish K.M. J. Org. Chem. 2007, 72, 2538-2542.

9. Epple L., Amsharov K., Simeonov K., Dix I., Jansen M. Chem. Commun. 2008, 5610-5612.

10. Konarev D.V., Khasanov S.S., Lyubovskaya R.N. Russ. Chem. Bull. 2007, 56, 371-392.

11. Saito G., Teramoto T., Otsuka A., Sugita Y., Ban T., Kusunoki M., Sakaguchi K. Synth. Met. 1994, 64, 359-368.

12. Konarev D.V., Khasanov S.S., Otsuka A., Saito G., Lyubovskaya. R.N. Inorg. Chem. 2007, 46, 2261-2271.

13. Konarev D.V., Khasanov S.S., Otsuka A., Saito G. Lyubovskaya. R.N. J. Am. Chem. Soc. 2006, 128, 9292-9293.

14. Konarev D.V., Khasanov S.S., Otsuka A., Saito G., Lyubovskaya R.N. J. Phys. Chem. B, submitted.

15. Konarev D.V., Khasanov S.S., Otsuka A., Saito G., Lyubovskaya R.N. Chem. Eur. J. 2006, 12, 5225-5230.

16. Konarev D.V., Khasanov S.S., Saito G., Lyubovskaya R.N. Cryst. Growth Des. 2009, 9, 1170-1181.

17. Konarev D.V., Khasanov S.S., Saito G., Lyubovskaya R.N. J. Porphyrins Phthalocyanines 2008, 1146-1153.

18. Scheidt W.R. J. Am. Chem. Soc. 1974, 96, 90-94.

19. Reed C.A., Kouba J.K., Grimes C.L., Cheung S.K. Inorg. Chem. 1978, 17, 2666-2670.

20. Scheidt W.R. J. Am. Chem. Soc. 1974, 96, 84-89.

21. Scheidt W.R., Cunningham J.A., Hoard J.L. J. Am. Chem. Soc. 1973, 95, 8289-8294.

22. Kirner J.F., Reed C.A., Scheidt W.R. J. Am. Chem. Soc. 1977, 99, 1093-1100.

23. Piciulo P.L., Rupprecht G., Scheidt W.R. J. Am. Chem. Soc 1974, 96, 5293-5295.

24. Kadish K.M., Boulas P.L., Vijayashree M.N., Subramanian R., Gao X., Mead S., Tan Z., Jones M.T. Proc. - Electrochem. Soc. 1995, 95-10, 213-228.

25. Luckhurst G.R., Pedulli G.F., Tiecco M. J. Chem. Soc. B 1971, 329-334

26. Kirner J.F., Reed C.A., Scheidt W.R. J. Am. Chem. Soc. 1977, 99, 2557-2563. 